\title{
SELF ESTEEM, SELF EFFICACY DAN PRESTASI AKADEMIK MAHASISWA AKUNTANSI: STUDI PADA KELAS PENGAUDITAN
}

\author{
Sidiq Ashari ${ }^{1}$, Eka Noor Asmara², Supardi ${ }^{3}$ \\ Akademi Akutansi YKPN ${ }^{1,2,3}$ \\ Email: mas sidiq@yahoo.com ${ }^{1}$
}

KETERANGAN ARTIKEL

Riwayat Artikel

Diterima: 1 Mei 2019

Direvisi: 1 Juni 2019

Disetujui: 31 Juni 2019

\section{Klasifikasi JEL}

12,129

Keyword: Self Esteem, Self Efficacy, Accademic Performance.

Kata Kunci: Self Esteem, Self Efficacy, Prestasi Akademik.

\section{ABSTRACT}

This study aims to provide empirical evidence of the related between self esteem and self efficacy with academic performance on auditing course. By using non-probability sampling techniques that is purposive sampling, this research using a sample of 194 university students in Yogyakarta that take on auditing course. This research model was developed based on previous research models by using survey in data collection process. Analysis uses structural equation models by using smartPLS software. Results of this research shown the support of 2 out of 3 proposed hypothesis, namely that there is a significant positive relationship between self esteem against self efficacy and academic performance. Meanwhile, this research can not proves that self efficacy strengthen academic performance on auditing course.

\begin{abstract}
ABSTRAK
Penelitian ini bertujuan untuk memberikan bukti empiris hubungan antara self esteem dan self efficacy dengan prestasi akademik pada kelas pengauditan. Dengan menggunakan teknik non-probability sampling yaitu purposive sampling, penelitian ini menggunakan sampel 194 mahasiswa di Yogyakarta yang mengikuti kelas pengauditan. Model penelitian ini dikembangkan berdasarkan model penelitian sebelumnya dengan menggunakan survei dalam proses pengumpulan data. Analisis menggunakan structural equation models dengan menggunakan perangkat lunak smartPLS. Hasil penelitian ini menunjukkan dukungan 2 dari 3 hipotesis yang diajukan, yaitu bahwa ada hubungan positif yang signifikan antara self esteem terhadap self efficacy dan prestasi akademik. Sementara itu, penelitian ini tidak dapat membuktikan bahwa self efficacy memperkuat prestasi akademik pada kelas pengauditan.
\end{abstract}

\section{PENDAHULUAN}

Sebelum International Standards on Auditing (ISA) diterapkan, auditor memahami standar teknis yang terdiri dari pernyataan standar auditing, pernyataan standar atestasi, pernyataan jasa akuntansi dan review, pernyataan jasa konsultasi, dan pernyataan standar pengendalian mutu. Standar auditing merupakan panduan audit atas laporan keuangan historis dan terdiri dari 10 standar serta dirinci dalam bentuk Pernyataan Standar Auditing (PSA). Standar ISA tidak membagi standar auditing seperti yang ada di Standar Profesional Akuntan Publik (SPAP) yaitu tidak ada Standar Umum, Standar Pekerjaan Lapangan dan Standar Pelaporan. Penyajian 
standar yang ada di International Standards on Auditing sudah mencerminkan proses pengerjaan audit. International Standards on Auditing berisi prinsip-prinsip dasar dan prosedur prosedur esensial bersama dengan panduan yang berhubungan dalam bentuk penjelasan dan materi yang lain.

Keputusan untuk mengadopsi dan mengimplementasikan International Standards on Auditing di Indonesia disebabkan karena adanya kekuatan pasar yang dimiliki oleh Kantor Akuntan Publik (KAP) yang mempunyai jaringan global (Big Four) dan jaringan internasional (second tier firms) terutama yang beroperasi di Indonesia (Tuanakotta, 2013). Bagi KAP yang melayani klien audit semacam itu, International Standards on Auditing bukan lagi pilihan atau lebih tepatnya "pilih International Standards on Auditing atau pilih keluar dari jaringan kerjasama global atau jaringan kerjasama internasional". Karena kebutuhan pasar tersebut, maka tenaga kerja harus memiliki kemampuan dan kualifikasi sesuai dengan kebutuhan pasar tenaga kerja bidang audit.

Pengadopsian International Standards on Auditing pada praktek pengauditan di Indonesia dan adanya kebutuhan tenaga kerja, seharusnya segera direspon oleh perguruan tinggi terutama yang berhubungan dengan kurikulumnya. Sebagai salah satu agen yang bertanggung jawab pada proses mempersiapkan tenaga kerja, perguruan tinggi sudah harus mengintregasikan International Standards on Auditing sebagai bahan ajar matakuliah pengauditan (Asmara dkk., 2016). Dengan memperbaiki kurikulum yang sesuai dengan kebutuhan pasar tenaga kerja khususnya auditor, diharapkan implementasi International Standards on Auditing dapat secara efektif dan efisien dipelajari oleh dosen dan mahasiswa. Sehingga mahasiswa maupun dosen dapat memahami secara komprehensif mengenai gagasan-gagasan dasar dan proses audit berbasis International Standards on Auditing serta mampu menjawab apa, mengapa dan bagaimana standar serta aturan
International Standards on Auditing berlaku (Tuanakotta, 2013).

Sebagai salah satu indikator pencapaian keberhasilan belajar mahasiswa, prestasi belajar mahasiswa merupakan manifestasi dari proses belajar yang dilakukan. Namun demikian, tidak semua mahasiswa dapat mencapai prestasi sesuai dengan potensi yang dimiliki, banyak di antara mahasiswa tidak menampilkan hasil optimal (Adhiputra, 2015). Hal ini disebabkan dalam proses belajar dan mengerjakan tugas-tugasnya mahasiswa seringkali tidak disiplin, kerap menunda dan cenderung menyerah dalam mengerjakan tugas-tugas yang diberikan (Fajarwati, 2015). Menurut Warsito (2009), terdapat beberapa fenomena yang berhubungan dengan prestasi akademik mahasiswa dan terjadi pada hampir semua perguruan tinggi adalah sering ditemukannya mahasiswa yang kurang yakin akan kemampuannya, mahasiswa kurang berusaha lebih keras, cepat menyerah dengan masalah-masalah yang ada, kurang serius dalam perkuliahan, dan lain sebagainya. Sikap dan perilaku yang ditunjukan oleh mahasiswa tersebut secara langsung maupun tidak langsung dapat mempengaruhi kinerja yang tampak pada prestasi akademik melalui nilai Indeks Prestasi (IP) dan Indeks Prestasi Kumulatif (IPK).

Mahasiswa yang memiliki ciri-ciri seperti yang disebutkan pada paragraf di atas dapat dikatakan sebagai mahasiswa yang memiliki keyakinan akan kemampuannya atau selfefficacy-nya rendah (Collins, 1982) dan memiliki harga diri atau self esteem yang bermasalah (Latifah dkk., 2011; Irawati dan Hajat, 2012; Indrawati, 2014). Bandura (1986) mendefinisikan self-efficacy sebagai judgement seseorang atas kemampuannya untuk merencanakan dan melaksanakan tindakan yang mengarah pada pencapaian tujuan tertentu. Dengan kata lain, self-efficacy adalah keyakinan penilaian diri berkenaan dengan kompetensi seseorang untuk sukses dalam tugas-tugasnya. Menurut Bandura (1997) individu yang memiliki self-efficacy 
yang rendah akan menghindari semua tugas dan menyerah dengan mudah ketika masalah muncul serta cenderung menganggap kegagalan sebagai kurangnya kemampuan yang ada. Self esteem adalah suatu keyakinan nilai diri sendiri berdasarkan evaluasi diri secara keseluruhan baik positif maupun negatif (Indrawati, 2014). Seseorang yang memiliki self esteem rendah (negatif) akan merasa lemah, tidak berdaya, dan akan memiliki masalah dalam berperilaku dengan lingkungan (Latifah dkk., 2011; Irawati dan Hajat, 2012).

Beberapa penelitian sebelumnya (Warsito, 2009; Latifah dkk., 2011; Irawati dan Hajat, 2012; Fajarwati, 2015) telah melakukan pengujian terhadap hubungan faktor-faktor individu terhadap prestasi akademik. Hasil penelitian-penelitian tersebut mendapatkan bukti empiris bahwa faktor-faktor individu mempunyai hubungan yang signifikan dengan prestasi akademik mahasiswa, akan tetapi tidak menunjukkan hasil yang konsisten. Oleh karena itu, penelitian ini akan melakukan pengujian kembali terhadap hubungan variabel self esteem, self efficacy dan prestasi akademik mahasiswa dengan subyek yang berbeda yaitu terhadap nilai yang diperoleh mahasiswa pada matakuliah pengauditan. $\mathrm{Hal}$ yang mendasari peneliti melakukan pengujian dengan objek mahasiswa yang menempuh matakuliah pengauditan karena peneliti melihat fenomena yang terjadi pada sebagian mahasiswa mengalami keadaan self-efficacy rendah atau self esteem negatif terutama dalam memahami matakuliah pengauditan yang saat ini telah mengadopsi standar yang relatif baru yaitu international standards on auditing (ISA).

Berdasarkan penjelasan tersebut dan hasil penelitian sebelumnya mengenai hubungan variabel self esteem, self efficacy dan kinerja individu, maka pertanyaan yang diajukan dalam penelitian ini adalah apakah self esteem dan self efficacy memiliki hubungan terhadap prestasi akademik mahasiswa khususnya pencapaian nilai mahasiswa pada matakuliah pengauditan? Oleh karena itu, sesuai dengan latar belakang masalah dan pertanyaan penelitian, maka penelitian ini bertujuan untuk menguji kembali hubungan antara variabel self esteem, self efficacy dan prestasi akademik mahasiswa berdasarkan persepsi mahasiswa yang sudah menempuh mata kuliah pengauditan.

\section{KAJIAN LITERATUR DAN PENGEMBANGAN HIPOTESIS}

\section{Teori Kognitif Sosial}

Teori kognitif sosial (social cognitive theory/SCT) merupakan model yang robust serta mulai banyak diterima dan secara empiris sudah banyak divalidasi untuk penelitian mengenai perilaku individu. Dalam Social Cognitive Theory, Bandura (1977; 1982; 1986) mengembangkan pandangan human functioning yang mana individu menyerasikan peran sentral kognitif, seolah mengalami sendiri (vicarious), pengaturan diri, dan proses reflektif diri dalam adaptasi dan perubahan manusia (Mukhid, 2009). Dalam perspektif kognitif sosial, individu dipandang berkemampuan proaktif dan mengatur diri daripada sebatas mampu berperilaku reaktif dan dikontrol oleh kekuatan biologis atau lingkungan. Selain itu, individu juga dipahami memiliki self-beliefs yang memungkinkan mereka berlatih mengukur pengendalian atas pikiran, perasaan, dan tindakan mereka. Bandura $(1977 ;$ 1982) memperlihatkan bahwa individu membuat dan mengembangkan persepsi diri atas kemampuan yang menjadi instrumen pada tujuan yang mereka kejar dan pada kontrol yang mereka latih atas lingkungannya.

Bandura (1977; 1982) menyatakan bahwa lingkungan atau karakteristik situasional mempengaruhi perilaku pada situasi tertentu yang kemudian gilirannya dipengaruhi kembali oleh perilaku. Selain itu, perilaku dipengaruhi oleh kognitif atau faktorfaktor personal dan gilirannya perilaku mempengaruhi faktor-faktor personal tersebut. Hubungan timbal balik antara 
lingkungan (karakteristik situasional), perilaku dan kognitif (faktor-faktor personal) disebut oleh Bandura (1977; 1982) sebagai hubungan timbal-balik segitiga (triadic reciprocality). Teori kognitif sosial berakar pada pandangan tentang humanagency bahwa individu merupakan agen yang secara proaktif mengikut sertakan dalam lingkungan mereka sendiri dan dapat membuat sesuatu terjadi dengan tindakan mereka. Adapun kunci pengertian agency adalah kenyataan bahwa di antara faktor personal yang lain, individu memiliki self-beliefs yang memungkinkan mereka melatih mengontrol atas pikiran, perasaan, dan tindakan mereka, bahwa "apa yang dipikirkan, dipercaya, dan dirasakan orang mempengaruhi bagaimana mereka bertindak" (Bandura, 1982).

\section{Self Efficacy}

Sebagai salah satu faktor individu yang dihasilkan pada social cognitive theory, selfefficacy didefinisikan oleh Bandura (1977; 1986) sebagai judgement seseorang atas kemampuannya untuk merencanakan dan melaksanakan tindakan yang mengarah pada pencapaian tujuan tertentu. Bandura (1997:3) menggunakan istilah self efficacy mengacu pada keyakinan (beliefs) tentang kemampuan seseorang untuk mengorganisasikan dan melaksanakan tindakan untuk pencapaian hasil atau sukses dalam tugas-tugasnya. Sedangkan menurut Hartono (2008:262), self efficacy adalah kepercayaan-kepercayaan tentang kemampuan seseorang untuk melakukan suatu perilaku tertentu. Self efficacy mempengaruhi pilihan-pilihan tentang melakukan perilaku, usaha dan persistensi untuk menghadapi halangan-halangan mencapai kinerja dari perilaku.

Menurut social cognitive theory, keyakinan self-efficacy mempengaruhi pilihan orang dalam membuat dan menjalankan tindakan yang mereka kejar. Hartono (2008:269) menyatakan bahwa dalam mendefinisikan self efficacy, sangat penting untuk meninjau dimensi dari self efficacy yang relevan yaitu besaran (magnitude), kekuatan (strength) dan generalisabilitas (generalizability). Besaran dari self efficacy berhubungan dengan tingkat kesulitan tugas yang dipercaya individu dapat melakukannya. Seseorang dengan besaran yang tinggi akan melihat dirinya sendiri mampu untuk menyelesaikan tugas-tugas yang rumit. Sedangkan yang memiliki besaran rendah, akan melihat dirinya sendiri hanya mampu melakukan tugas-tugas yang sederhana dari perilaku.

Keyakinan self efficacy juga membantu menentukan sejauh mana usaha yang akan dikerahkan orang dalam suatu aktivitas, seberapa lama mereka akan gigih ketika menghadapi rintangan, dan seberapa ulet mereka akan menghadapi situasi yang tidak cocok (Schunk, 1981). Kekuatan dari self efficacy berhubungan dengan tingkat keyakinan seseorang tentang pertimbangan yang akan dilakukan. Individual dengan kekuatan lemah dari self efficacy akan lebih mudah frustasi karena adanya halangan yang menghambat kinerja mereka. Kebalikannya, individual dengan kekuatan yang kuat dari self efficacy tidak akan gentar dengan permasalahan sulit.

Generalisabilitas dari self efficacy menunjukkan seberapa jauh persepsi dari self efficacy terbatas pada situasi-situasi tertentu. Masing-masing individu akan merasa memiliki kemampuan yang berbeda-beda dalam melakukan perilaku pada kondisi yang berbeda. Menurut Mukhid (2009), keyakinan kemampuan seseorang dapat membantu menentukan hasil yang diharapkan, karena individu memiliki confident dalam mengantisipasi hasil yang sukses. Misalnya, pebelajar yang confident dalam mengantisipasi kemampuan menulis, memiliki nilai yang tinggi dalam tugas kepenulisan dan mengharapkan mutu tugas mereka memperoleh manfaat akademik. Sebaliknya, pebelajar yang ragu-ragu atas kemampuan menulis berpretensi akan memperoleh nilai rendah sebelum mereka mantap mulai 
menulis. Individu yang confident, memandang tugas-tugas yang sulit sebagai tantangan untuk dikuasai daripada sebagai ancaman untuk dihindari. Mereka memiliki minat yang lebih kuat dan keasyikan yang mendalam pada kegiatan, menyusun tujuan yang menantang mereka, dan memelihara komitmen yang kuat serta mempertinggi dan mendukung usahausaha mereka dalam menghadapi kegagalan. Sebaliknya, orang yang meragukan kemampuan dirinya, mereka bisa percaya bahwa sesuatu itu lebih sulit daripada yang sesungguhnya (Mukhid, 2009).

\section{Self Esteem}

Self esteem merupakan suatu keyakinan nilai diri sendiri berdasarkan evaluasi diri secara keseluruhan baik yang bersifat positif maupun negatif (Gardner, 2004). Menurut Indrawati (2014), self esteem yang tinggi (positif) akan membangkitkan rasa percaya diri, penghargaan diri, rasa yakin akan kemampuan diri, rasa bahwa kehadirannya diperlukan di dalam dunia ini. Orang yang mempunyai Self esteem yang kuat akan mampu membina relasi yang lebih baik dan sehat dengan orang lain, bersikap sopan dan menjadikan dirinya menjadi orang yang berhasil (Sapariyah, 2008). Sedangkan individu dengan self esteem yang rendah (negatif) cenderung tidak berani mencari tantangantantangan baru dalam hidupnya, lebih senang menghadapi hal-hal yang sudah dikenal dengan baik serta menyenangi hal-hal yang tidak penuh dengan tuntutan, tidak mampu berkomunikasi dengan orang lain, dan cenderung merasa hidupnya tidak bahagia (Indrawati, 2014). Selain itu, individu yang memiliki self esteem yang rendah memiliki citra diri negatif dan konsep diri yang buruk. Semuanya akan menjadi penghalang kemampuannya sendiri dalam membentuk satu hubungan antar individu agar nyaman dan baik untuk dirinya. Bahkan seringkali menghukum dirinya sendiri atas ketidakmampuannya dan terlarut dalam penyesalan (Sapariyah, 2008).
Menurut Adhiputra (2015), self esteem merupakan komponen penting dalam menentukan prestasi belajar mahasiswa. Mahasiswa yang memiliki self esteem tinggi akan membangkitkan rasa percaya diri, rasa yakin akan kemampuan diri, rasa berguna serta rasa bahwa kehadirannya diperlukan di dunia ini. Selain itu mahasiswa juga akan memiliki kepercayaan diri dapat mencapai prestasi yang dia dan orang lain harapkan. Pada gilirannya, keyakinan itu akan memotivasi mahasiswa tersebut untuk sungguh-sungguh mencapai apa yang dicitacitakan. Self esteem lebih mendasar daripada reputasi dan prestise karena mencerminkan hasrat bagi kekuatan, pencapaian, ketepatan, penguasaan dan kompetensi, keyakinan diri menghadapi dunia, independensi dan kebebasan. Dengan kata lain, self esteem didasarkan pada kompetensi nyata dan bukan sekedar opini orang lain (Adhiputra, 2015). Sedangkan mahasiswa yang memiliki self esteem rendah cenderung akan bersikap pasif dan agresif. Menurut Sapariyah (2008), sikap pasif yaitu sikap yang tidak tegas dalam melakukan berbagai tindakan akibat adanya rasa takut membuat orang lain tersinggung, merasa diperintah atau digurui yang membuat diri menjadi benci dan merasa dikucilkan. Sikap agresif dalam hal ini yaitu memaksakan gagasan, tidak mau menerima masukan dari orang lain dan cenderung mengundang perdebatan daripada menyelesaikan masalah, padahal sikap menentang dan mengabaikan ide-ide orang lain berarti menghambat tercapainya keputusan yang tepat dan akurat (Sapariyah, 2008).

\section{Prestasi Akademik}

Keberhasilan mahasiswa
menyesuaikan dalam
akademiknya, ditandai dengan prestasi
akademik yaitu melalui perolehan nilai-nilai
yang optimal pada setiap matakuliah yang
ditempuh dan dapat juga dilihat melalui
Indeks Prestasi (IP) maupun Indeks Prestasi
Kumulatif (IPK) serta ketepatan waktu dalam


menyelesaikan studi. Menurut Fasikhah dan Fatimah (2013), prestasi akademik adalah hasil belajar dalam bidang akademis yang merefleksikan kemampuan dan kinerja mahasiswa terhadap materi pelajaran yang bersifat multidimensi yang mencakup aspek kognitif, afektif dan psikomotor, yang diberikan oleh pendidik kepada peserta didik yang lazimnya ditunjukkan dengan nilai. Sedangkan Haripoernomo (2003) mendefinisikan prestasi akademik merupakan indikator kunci yang menunjukkan penguasaan seorang mahasiswa terhadap materi pengetahuan dan ketrampilan yang diajarkan di perguruan tinggi.

Berdasarkan perspektif kognitif sosial, Clemons (2008) berpandangan bahwa prestasi akademik sebagai hubungan yang kompleks antara kemampuan individu, persepsi diri, penilaian terhadap tugas, harapan akan kesuksesan, strategi kognitif dan regulasi diri, gender, gaya pengasuhan, status sosioekonomi, kinerja dan sikap individu terhadap sekolah. Hal ini menunjukkan bahwa, prestasi akademik individu ditentukan oleh dua faktor, baik eksternal maupun internal. Faktor internal yang dapat mempengaruhi prestasi akademik adalah kemampuan intelektual, minat, bakat dan sikap. Sedangkan faktor eksternal yang dapat mempengaruhi prestasi akademik umumnya terdiri dari lingkungan kampus, lingkungan keluarga dan lingkungan masyarakat.

\section{Pengembangan Hipotesis \\ Hubungan Self Esteem dan Self Efficacy}

Menurut Gardner (2004), self esteem merupakan suatu keyakinan nilai diri sendiri berdasarkan evaluasi diri secara keseluruhan baik yang bersifat positif maupun negatif. Orang yang mempunyai Self esteem yang kuat akan mampu membangkitkan rasa percaya diri, rasa yakin akan kemampuan diri, dapat membina relasi yang lebih baik dan sehat dengan orang lain, bersikap sopan dan menjadikan dirinya menjadi orang yang berhasil (Sapariyah, 2008; Indrawati, 2014).
Sedangkan individu dengan self esteem yang rendah (negatif) cenderung tidak berani mencari tantangan-tantangan baru dalam hidupnya, lebih senang menghadapi hal-hal yang sudah dikenal dengan baik serta menyenangi hal-hal yang tidak penuh dengan tuntutan, tidak mampu berkomunikasi dengan orang lain, dan cenderung merasa hidupnya tidak bahagia (Indrawati, 2014).

Self efficacy merupakan penilaian individu terhadap kemampuan atau kompetensinya untuk melakukan tugas, mencapai suatu tujuan, dan menghasilkan sesuatu (Baron dan Byrne, 1994). Individu yang memiliki self efficacy yang tinggi akan mencurahkan semua usaha dan perhatiannya untuk mencapai tujuan yang telah ditentukan (Indrawati, 2014). Keyakinan self efficacy dapat membantu seseorang untuk menentukan seberapa besar usaha yang akan dikerahkan, seberapa lama kegigihan individu ketika menghadapi rintangan, dan seberapa ulet individu dalam menghadapi dan menyelesaikan situasi yang tidak cocok. Dengan kata lain individual dengan kekuatan yang kuat dari self efficacy tidak akan gentar dengan permasalahan sulit yang dihadapi. Kebalikannya, individual dengan kekuatan lemah dari self efficacy akan lebih mudah frustasi karena adanya halangan yang menghambat kinerja mereka.

Karena Self esteem dan self efficacy berkaitan dengan personalitas seseorang, maka individu yang merasa dirinya begitu berarti, berharga dan dapat diterima dalam lingkungan organisasi dapat meningkatkan keyakinan atau kepercayaan terhadap kemampuannya dalam menjalankan setiap tugas dan diyakini tugas itu akan berhasil. Sehingga sesuai dengan penelitian yang dilakukan oleh Schyns dan Collani (2002), Engko (2006) dan Indrawati (2014), maka penelitian ini sepakat dengan penelitianpenelitian tersebut bahwa ada hubungan positif antara self esteem dan self efficacy. Atas uraian diatas maka hipotesis yang 
diajukan dalam penelitian ini adalah sebagai berikut:

\section{H1: Self esteem memiliki hubungan positif terhadap self efficacy}

\section{Hubungan Self Esteem dan Prestasi Akademik}

Harga diri (self esteem) merupakan komponen penting dalam menentukan prestasi belajar mahasiswa (Adiputra, 2015; Wibowo, 2016). Harga diri yang dimiliki mahasiswa seharusnya dapat memberikan kontribusi positif terhadap prestasi belajar. Mahasiswa yang memiliki self esteem tinggi akan membangkitkan rasa percaya diri, rasa yakin akan kemampuan diri, rasa berguna serta rasa bahwa kehadirannya diperlukan di dunia ini (Adiputra, 2015). Keyakinan terhadap harga diri tersebut akan memotivasi seseorang tersebut untuk sungguh-sungguh mencapai apa yang dicita-citakan. Sedangkan seseorang dengan self esteem yang rendah akan lebih rentan berperilaku negatif karena self esteem dapat mempengaruhi perilaku seseorang, sehingga di kampus secara tidak langsung mahasiswa akan menghadapi masalah-masalah karena perilaku negatif akibat self esteem rendah.

Penelitian sebelumnya telah dilakukan untuk membuktikan keterkaitan antara self esteem dengan prestasi belajar. Temuan dalam penelitian-penelitian sebelumnya diperoleh hasil yang berbeda-beda. Penelitian yang dilakukan oleh Lockett dan Harrell (2003); Colquhoun dan Bourne (2012); dan Adiputra (2015) diperoleh hasil bahwa terdapat korelasi antara self esteem dengan prestasi akademik. Sedangkan penelitian yang menyatakan bahwa tidak terdapat korelasi antara kedua variabel tersebut, walaupun ada, korelasinya sangat kecil (Di Giunta., dkk., 2013; Zheng, dkk., 2014). Sedangkan penelitian yang dilakukan oleh Afari dkk. (2012) menyatakan bahwa self esteem baru dapat mempengaruhi prestasi akademik, jika terdapat variabel lain yang ikut diteliti. Oleh sebab itu, berdasarkan hasil penelitianpenelitian terdahulu membuktikan bahwa hubungan antara self esteem dan prestasi akademik masih menjadi perdebatan yang menarik untuk diteliti (Wibowo, 2016).

Berdasarkan penjelasan bahwa self esteem merupakan variabel yang mempengaruhi banyak perilaku manusia, maka self esteem akan sangat mungkin mempengaruhi perilaku manusia untuk mendapatkan prestasi akademik. Dan sesuai dengan hasil penelitian yang dilakukan oleh Lockett dan Harrell (2003); Colquhoun dan Bourne (2012); Adiputra (2015) dan Wibowo (2016) yang menyatakan bahwa self esteem berpengaruh terhadap prestasi akademik, maka hipotesis yang diajukan dalam penelitian ini adalah:

H2: Self esteem memiliki hubungan positif terhadap prestasi akademik mahasiswa

\section{Hubungan Self Efficacy dan Prestasi Akademik}

Menurut Bandura $(1977 ; 1986)$ Selfefficacy adalah suatu keyakinan individu bahwa dirinya mampu untuk melakukan sesuatu dalam situasi tertentu dengan berhasil. Self efficacy menekankan kepada aspek keyakinan diri dalam melakukan tindakan tugas dan tindakan dimana seharusnya seseorang dapat melakukan sebuah tindakan dari apa yang dimilikinya. Bandura (1999) juga menyatakan bahwa self efficacy merupakan keyakinan akan kemampuan individu untuk dapat mengorganisasi dan melaksanakan serangkaian tindakan yang dianggap perlu sehingga mencapai suatu hasil sesuai harapan. $\mathrm{Di}$ antara pengaruh-pengaruh internal, self efficacy merupakan bentuk evaluasi diri yang berkaitan dengan persepsi individu terhadap kompetensi dan kemampuan dalam menyelesaikan tugastugas tertentu. Menurut Warsito (2009), seseorang dapat memiliki keyakinan yang tinggi pada suatu tugas atau situasi tertentu, namun pada situasi dan tugas yang lain tidak. Umumnya self-efficacy akan memprediksi 
dengan baik suatu tampilan yang berkaitan erat dengan keyakinan tersebut.

Berdasarkan penjelasan di atas, untuk mencapai prestasi akademik yang baik, seorang mahasiswa harus yakin akan kemampuan yang dimiliki. Self-efficacy membantu mahasiswa untuk memenuhi tuntutan dan persyaratan akademis dengan keyakinan akan kapabilitas yang dimiliki untuk mencapai prestasi akademik yang baik. Hal ini didukung juga terhadap hasil penelitian yang dilakukan Warsito (2009) dan Adiputra (2015), yang menyatakan bahwa self efficacy berpengaruh positif terhadap prestasi akademik. Oleh karena itu, dari penjelasan- penjelasan tersebut, maka hipotesis yang diusulkan dalam penelitian ini adalah:

\section{H3: Self efficacy memiliki hubungan positif} terhadap prestasi akademik.

\section{Model Penelitian}

Gambar 1 menunjukkan model yang dibangun dalam penelitian ini. Model melibatkan tiga variabel yang berasal dari penelitian-penelitian sebelumnya yaitu, variabel independen yang terdiri dari variabel individu yang diwakilkan oleh self esteem dan self efficacy serta variabel dependen yaitu prestasi akademik mahasiswa untuk mata kuliah pengauditan.

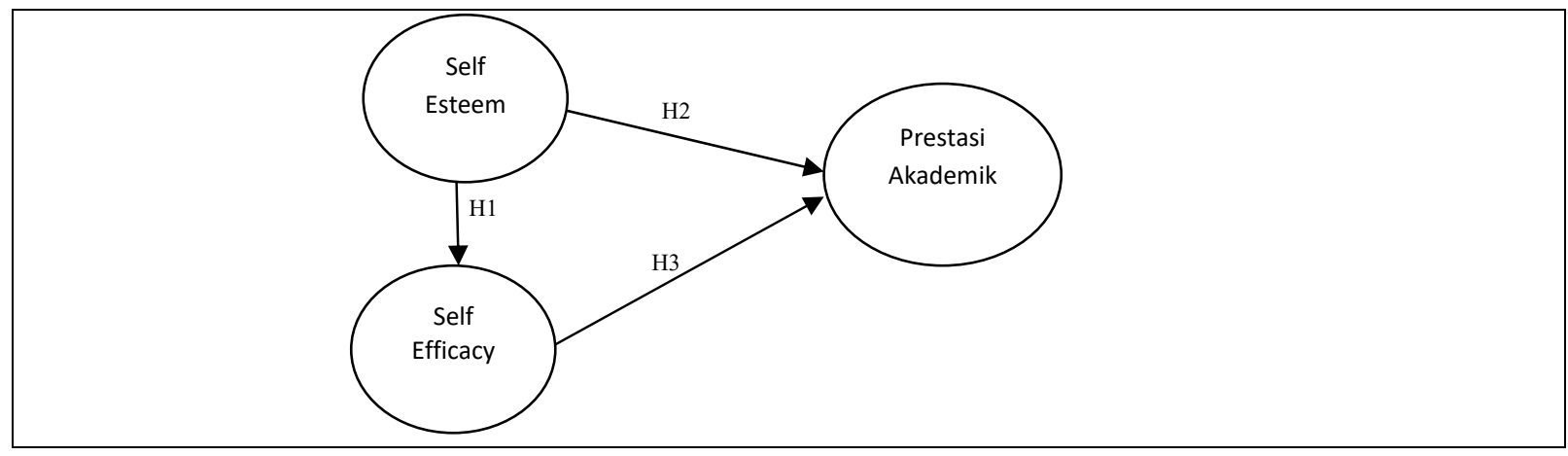

Gambar 1. Model Penelitian

\section{METODE PENELITIAN}

\section{Desain Penelitian}

Penelitian ini menggunakan desain penelitian sebab akibat atau penelitian kausalitas yang berguna untuk menganalisis hubungan antar variabel dan pengaruh variabel satu dengan variabel lainnya melalui pengujian hipotesis. Pengujian hipotesis menggunakan model prediksi yang bertujuan menguji efek prediksi antar variabel laten untuk melihat apakah ada hubungan atau pengaruh antarvariabel tersebut. Dimensi waktu yang digunakan dalam penelitian ini adalah melibatkan satu waktu tertentu dengan banyak sampel (cross-sectional).

\section{Populasi dan Sampel Penelitian}

Populasi dalam penelitian ini meliputi seluruh mahasiswa yang kuliah pada Fakultas Ekonomi pada perguruan tinggi di Yogyakarta.
Sampel yang digunakan dalam penelitian ini meliputi mahasiswa jurusan akuntansi yang sudah menempuh matakuliah pengauditan. Metode pengambilan sampel yang digunakan dalam penelitian ini adalah purposive sampling. Kriteria yang ditentukan dalam memperoleh sampel penelitian adalah mahasiswa yang masih aktif dan pernah menempuh matakuliah pengauditan yang telah mengadopsi International Standards on Auditing.

\section{Metode Pengumpulan Data}

Data yang akan dikumpulkan dalam penelitian ini adalah data primer, yaitu data yang dikumpulkan secara langsung oleh peneliti kepada sumber data dan belum pernah diolah oleh pihak manapun untuk tujuan penelitian tertentu. Metoda pengumpulan data dilakukan dengan 
mengirimkan kuesioner (survey) kepada mahasiswa yang termasuk ke dalam sampel tersebut. Tanggapan mahasiswa yang diperoleh melalui pengisian kuesioner menggunakan skala Likert sesuai dengan pertanyaan masing-masing bagian.

\section{Teknis dan Alat Analisis}

Penelitian ini menggunakan alat analisis Partial Least Square (PLS) yang digunakan untuk menguji hipotesis yang diajukan. PLS adalah teknik Structural Equation Modeling (SEM) berbasis varian yang secara simultan dapat melakukan pengujian model pengukuran sekaligus pengujian model struktural (Hartono dan Abdillah, 2009:14). PLS juga bertujuan untuk memprediksi model untuk pengembangan teori. Oleh sebab itu, analisis PLS melibatkan dua tahapan, yaitu menilai model pengukurannya (reliabilitas dan validitas diskriminan dari pengukur-pengukur) dan menilai dari model struktural.

Pengujian model pengukuran dilakukan dengan pengujian validitas konstruk dan pengujian reliabilitas. Validitas konstruk terdiri dari validitas konvergen dan validitas diskriminan. Pengujian validitas konvergen dilakukan dengan melihat nilai AVE dan membandingkan antara akar AVE dengan korelasi konstruk variabel laten. Nilai AVE harus $>0,5$ sedangkan akar AVE harus lebih tinggi daripada nilai korelasi konstruk lainnya (Hartono dan Abdillah, 2009). Untuk pengujian validitas diskriminan, indikator pada suatu konstruk akan mempunyai nilai loading factor lebih besar pada konstruk yang dibentuknya daripada loading factor pada konstruk lain. Kriterianya loading factor secara praktikal memenuhi nilai $>0,50$ (Hartono dan Abdillah, 2009: 60). Sedangkan pengujianreliabilitas konstruk dapat diukur menggunakan Cronbach's alpha dan composite reliability. Konstruk dapat dikatakan reliabel jika nilai Cronbach's alpha lebih besar dari 0,60 dan nilai Composite reliability lebih besar dari 0,70 (Hartono dan Abdillah, 2009: 81).
Model struktural dalam PLS dievaluasi dengan menggunakan $R^{2}$ untuk konstruk dependen dan nilai koefisien path atau $t$ values tiap path untuk uji signifikansi antar konstruk (Hartono dan Abdillah, 2009: 62). Nilai $R^{2}$ digunakan untuk mengukur tingkat variasi perubahan variabel independen terhadap variabel dependen. Tingkat signifikansi pengujian hipotesis ditunjukkan dengan nilai koefiesien path yang ditunjukkan oleh nilai t-statistik. Untuk pengujian hipotesis pada alpha 5\% nilai t-statistik diatas 1,64 dan di atas 2,33 pada alpha $1 \%$ untuk hipotesis satu ekor (one-tailed) (Hartono dan Abdillah, 2009: 63).

\section{Definisi Operasional dan Variabel Penelitian}

Definisi operasional yang digunakan dan instrumen pengukuran variabel dapat dijelaskan sebagai berikut:

1. Self Esteem

Self-esteem merupakan suatu keyakinan yang dimiliki sesorang berdasarkan evaluasi diri secara keseluruhan.Variabel self esteem diukur dengan menggunakan instrumen yang dikembangkan oleh Rosenberg (1980) dengan 10 pertanyaan yang memiliki tingkat validitas dan reliabilitas yang telah teruji.Variabel selfesteem di ukur dengan Skala Likert lima poin yaitu nilai 1 untuk jawaban sangat tidak setuju (STS), nilai 2 untuk jawaban tidak setuju (TS), nilai 3 untuk jawaban ragu-ragu (RR), nilai 4 untuk jawaban setuju (S), nilai 5 untuk jawaban sangat setuju (SS).

2. Self-Efficacy

Self-efficacy merupakan keyakinan seseorang terhadap kemampuan atau kopetensinya untuk melakukan sebuah tugas, mencapai tujuan atau mengatasi hambatan. Variabel self efficacy diukur dengan menggunakan instrumen yang dikembangkan oleh Bandura $(1977,1978)$ dan digunakan oleh Jones (1986). Instrumen yang berkaitan dengan self efficacy terdiri dari 8 item pertanyaan dan 
telah teruji melalui uji validitas dan reliabilitas sehingga instrumen tersebut konsisten dan cukup handal dalam mengukur variabel self efficacy.Variabel self-efficacy diukur dengan Skala Likert lima poin yaitu nilai 1 untuk jawaban sangat tidak setuju (STS), nilai 2 untuk jawaban tidak setuju (TS), nilai 3 untuk jawaban ragu-ragu (RR), nilai 4 untuk jawaban setuju (S), nilai 5 untuk jawaban sangat setuju (SS).

3. Prestasi Akademik

Prestasi akademik adalah hasil belajar dalam bidang akademis yang merefleksikan kemampuan dan kinerja mahasiswa terhadap materi pelajaran yang bersifat multidimensi yang mencakup aspek kognitif, afektif dan psikomotor, yang diberikan oleh pendidik kepada peserta didik yang lazimnya ditunjukkan dengan nilai (Fasikhah dan Fatimah, 2013). Variabel prestasi akademik diukur dengan melihat prestasi belajar mahasiswa menggunakan penilaian yang mengacu pada nilai yang diperoleh pada matakuliah pengauditan, baik pengauditan 1 (pengantar) maupun pengauditan 2 (lanjutan). Untuk nilai 4, 3, 2, 1, dan 0 secara berurutan mewakili nilai huruf yang diperoleh responden yaitu $A, B, C, D$ dan $E$.

\section{HASIL DAN PEMBAHASAN}

\section{Gambaran Umum Responden}

Data dalam penelitian ini diperoleh dari penyebaran 214 kuesioner pada mahasiswa akuntansi khususnya yang telah menempuh mata kuliah Pengauditan 1 dan Pengauditan 2. Penyebaran kuesioner dilakukan dengan cara mengumpulkan responden dalam kelas yang terbagi menjadi 3 sesi dan meminta para responden untuk mengisi pernyataanpernyataan kuesioner tersebut. Dari jumlah kuesioner yang diisi oleh para responden, sebanyak 20 kuesioner tidak dapat digunakan karena pengisian data yang tidak lengkap atau memberikan tanggapan yang tidak rasional sehingga dikeluarkan dari daftar sampel.
Kuesioner yang dikeluarkan tersebut sesuai dengan saran Cooper dan Schindler (2006:125), bahwa penanganan kuesioner yang tidak lengkap dan masalah dalam pola jawaban responden, salah satu penanganannya dapat dilakukan dengan mengeluarkan dari daftar sampel.

Berdasarkan hasil distribusi frekuensi yang diolah, dari 194 responden dalam penelitian ini didominasi oleh responden perempuan dibandingkan dengan responden laki-laki dengan perbandingan antara laki-laki dan perempuan adalah $35,47 \%$ dan $64,53 \%$. Responden laki-laki (mahasiswa) memiliki nilai mata kuliah pengauditan 1 dan pengauditan 2 dengan rentang C- sampai A dengan IPK antara 2,1 sampai 3,75. Sedangkan nilai mata kuliah pengauditan 1 dan pengauditan 2 untuk responden perempuan (mahasiswi) direntang nilai C+ sampai A dan IPK direntang 2,63 sampai dengan IPK 3,90 . Sehingga penyebaran prestasi akademik yang diperoleh oleh para responden baik laki-laki maupun perempuan, dapat terwakilkan dan dapat digunakan dalam penelitian ini.

\section{Model Pengukuran (Outer Model)}

Model pengukuran atau outer model yang merupakan hubungan antara indikatorindikator dengan konstruk yang digunakan dalam penelitian, apat menguji sejauh mana indikator-indikator pengukur sesuai dengan teori-teori yang digunakan untuk mendefinisikan suatu konstruk. Fokus utama dalam outer model adalah pengukuran validitas konstruk dan reliabilitas konstruk. Menurut Cooper dan Schindler (2006:102), uji validitas dilakukan untuk mengetahui kemampuan instrumen penelitian mengukur apa yang seharusnya diukur. Sedangkan uji reliabilitas digunakan untuk mengukur konsistensi alat ukur dalam mengukur suatu konsep. Sehingga pengukuran validitas konstruk menggunakan validitas konvergen dan validitas diskriminan, sedangkan reliabilitas konstruk dinilai dengan skor Cronbach's alpha untuk reliabilitas batas 
bawah dan Composite reliability untuk reliabilitas sesungguhnya.

\section{Validitas Konvergen}

Validitas konvergen berhubungan dengan prinsip bahwa pengukur-pengukur dari suatu kontruk seharusnya berkorelasi tinggi (Hartono dan Abdillah, 2009). Validitas konvergen terjadi jika skor yang diperoleh dari dua instrumen yang berbeda yang mengukur konstruk yang sama mempunyai korelasi tinggi. Parameter validitas konvergen dapat dilihat dari skor faktor loading, AVE dan Communality. Pada penelitian ini, peneliti menggunakan skor AVE dan Communality untuk mengukur validitas konvergen.

Menurut Chin (1995), nilai AVE dan Communality untuk masing-masing konstruk harus bernilai di atas 0,5 dan semakin tinggi nilai AVE dan Communality, maka semakin baik validitas konvergen masing-masing konstruk. Hartono dan Abdillah (2009:60) mengatakan bahwa nilai AVE dan Communality yang di atas 0,5 mengandung arti bahwa probabilitas indikator di suatu konstruk masuk ke variabel lain menjadi rendah dan masuk di konstruk yang dimaksud akan lebih besar (di atas 50\%). Berdasarkan hasil pengujian model pengukuran, tampak bahwa semua indikator memiliki skor AVE dan Communality di atas 0,5 . Sehingga dapat disimpulkan untuk indikator pada penelitian ini memiliki nilai AVE serta Communality yang signifikan dan dapat dikatakan bahwa model dalam penelitian ini memenuhi validitas konvergen.

Tabel 1. Nilai AVE, Akar AVE dan Communality

\begin{tabular}{lcccc}
\hline & AVE & Akar AVE & Communality & Keterangan \\
\hline Prestasi Akademik & 0,883581 & 0,939989 & 0,883581 & Valid \\
\hline Self Efficacy & 0,903401 & 0,950474 & 0,903401 & Valid \\
\hline Self Esteem & 0,763939 & 0,874036 & 0,763939 & Valid
\end{tabular}

Sumber: Data primer diolah, 2018 (Output SmartPLS 2.0, kecuali akar AVE)

\section{Validitas Diskriminan}

Pengukuran validitas diskriminan dapat dinilai dengan menggunakan skor cross loading atau dengan membandingkan square root of average variance extracted (akar AVE) untuk setiap konstruk dengan korelasi antar konstruk dalam model (Hartono dan Abdillah, 2009:61). Model mempunyai validitas diskriminan yang cukup jika skor cross loading di atas 0,70 dan akar AVE untuk setiap konstruk lebih besar daripada korelasi antara konstruk dengan konstruk lainnya dalam model. Sehingga dengan terpenuhi semua ukuran tersebut, maka validitas diskriminan yang berhubungan dengan prinsip bahwa pengukur-pengukur konstruk yang berbeda seharusnya tidak berkorelasi dengan tinggi.
Sebelum hasil cross loading ditampilkan dalam Tabel 2, ada beberapa indikator yang dihapus dari masing-masing konstruk karena nilai cross loading yang lebih rendah dibandingkan dengan konstruk lainnya. Indikator yang dihapus adalah self efficacy 5, self esteem 4, self esteem 5 dan self esteem 7 . Pada Tabel 2 di bawah, tampak bahwa hasil pengujian tiap indikator dalam satu konstruk memiliki skor loading yang lebih tinggi dibandingkan dengan indikator yang berbeda konstruk. Masing-masing indikator untuk setiap konstruk mempunyai skor cross loading di atas 0,70 dan mengumpul pada konstruknya sendiri. Sehingga berdasarkan output cross loading data yang digunakan memenuhi uji validitas diskriminan. 
Sidiq Ashari: Self Esteem, Self Efficacy dan ...

Tabel 2. Cross Loading

\begin{tabular}{lccc}
\hline & Self Efficacy & Self Esteem & Prestasi Akademik \\
\hline Efficacy 1 & 0.986529 & 0.740711 & -0.065682 \\
\hline Efficacy 2 & 0.944445 & 0.717251 & -0.099858 \\
\hline Efficacy 3 & 0.983269 & 0.747301 & -0.066609 \\
\hline Efficacy 4 & 0.985491 & 0.736196 & -0.072388 \\
\hline Efficacy 6 & 0.936712 & 0.694382 & -0.069611 \\
\hline Efficacy 7 & 0.985491 & 0.736196 & -0.072388 \\
\hline Efficacy 8 & 0.819731 & 0.713303 & -0.002561 \\
\hline Esteem 1 & 0.641943 & 0.880631 & 0.015421 \\
\hline Esteem 2 & 0.691208 & 0.880428 & 0.052606 \\
\hline Esteem 3 & 0.666788 & 0.904538 & 0.049699 \\
\hline Esteem 6 & 0.677019 & 0.910342 & 0.044821 \\
\hline Esteem 8 & 0.678438 & 0.828488 & 0.007922 \\
\hline Esteem 9 & 0.652172 & 0.886337 & 0.011117 \\
\hline Esteem 10 & 0.669009 & 0.823416 & 0.013126 \\
\hline Prestasi Akademik 1 & -0.020106 & 0.053126 & 0.913841 \\
\hline Prestasi Akademik 2 & -0.092254 & 0.015771 & 0.965431
\end{tabular}

Metode lain yang digunakan untuk mengukur validitas diskriminan adalah dengan melihat skor root square of average variance extracted (akar AVE). Pada Tabel 3 disajikan perbandingan antara akar AVE masing-masing konstruk dengan elemen-elemen yang mewakili variansi terdistribusi antar konstruk (korelasi antar variabel laten). Hasilnya menunjukkan bahwa nilai dari akar AVE lebih tinggi dari korelasi antar variabel. Hal ini menjelaskan bahwa tiap pengukur konstruk yang berbeda tidak berkorelasi tinggi, sehingga pengujian validitas diskriminan menggunakan perbandingan akar AVE dan korelasi antara konstruk telah terpenuhi.

Tabel 3. Korelasi Variabel

\begin{tabular}{cccc}
\hline & Prestasi Akademik & Self Efficacy & Self Esteem \\
\hline Prestasi Akademik & 0,939989 & & \\
\hline Self Efficacy & $-0,067757$ & 0,950474 & \\
\hline Self Esteem & 0,032134 & 0,765354 & 0,874036 \\
\hline
\end{tabular}

Sumber: Data primer diolah, 2018 (Output SmartPLS 2.0, kecuali Akar AVE)

\section{Uji Reliabilitas}

Selain uji validitas, model pengukuran dengan menggunakan PLS juga melakukan pengujian reliabilitas. Reliabilitas suatu pengukur menunjukkan stabilitas dan konsistensi dari suatu instrumen mengukur suatu konsep atau suatu variabel (Cooper dan Schindler, 2006: Hair dkk., 2006). Uji reliabilitas dalam PLS dapat diukur dengan menggunakan nilai Cronbach's alpha dan Composite Reability. Cronbach's alpha mengukur batas bawah nilai reliabilitas suatu konstruk sedangkan Composite Reliability mengukur nilai sesungguhnya reliabilitas suatu konstruk (Hartono dan Abdillah, 2009:62). Rule of thumb nilai alpha atau Composite Reliability harus lebih besar dari 0,7. 
Tabel 4. Nilai Composite Reliability dan Cronbach's Alpha

\begin{tabular}{lccc}
\hline & $\begin{array}{c}\text { Composite } \\
\text { Reliability }\end{array}$ & $\begin{array}{c}\text { Cronbachs } \\
\text { Alpha }\end{array}$ & Kriteria \\
\hline Prestasi Akademik & 0,938149 & 0,874130 & Tinggi \\
\hline Self Efficacy & 0,984902 & 0,981534 & Tinggi \\
\hline Self Esteem & 0,957669 & 0,948217 & Tinggi
\end{tabular}

Sumber: Data primer diolah, 2018 (Output SmartPLS 2.0)

Hasil pengujian pada Tabel 4 memperlihatkan bahwa nilai Cronbach's alpha dan Composite reliability $>0,70$, serta nilai Composite reliability lebih tinggi dari nilai Cronbach's alpha. Tampak dalam Tabel 4, nilai Cronbach's alpha terendah pada konstruk prestasi akademik sebesar 0,874130 dan tertinggi pada konstruk self efficacy sebesar 0,981534. Pada pengujian Composite reliability dihasilkan nilai terendah pada konstruk prestasi akademik sebesar 0,938149 dan tertinggi pada konstruk self efficacy sebesar 0,984902. Berdasarkan hasil pengujian tersebut, maka dapat dikatakan bahwa data yang digunakan telah memenuhi kriteria reliabilitas. Sehingga data yang digunakan dalam penelitian ini telah menunjukkan keakurasian, konsistensi dan ketepatan dalam melakukan pengukuran terhadap konsep atau teori dari masing-masing konstruk.

\section{Model Struktural (Inner Model)}

Pengujian model struktural dilakukan untuk menilai signifikansi hubungan antara konstruk satu dengan konstruk lainnya yang terdapat dalam model penelitian. Pengujian model struktural dari PLS dilakukan dengan menggunakan fungsi bootstrapping. Hasil pengujian yang tampak pada Tabel 5 menunjukkan nilai $R$-square sebesar 2,16\% untuk konstruk prestasi akademik dan 58,57\% untuk konstruk self efficacy. Hal ini mengandung arti variasi perubahan konstruk prestasi akademik sebesar 2,16\%. dijelaskan oleh variabel self efficacy dan self esteem, sisanya dijelaskan oleh variabel lain di luar model yang diajukan. Begitu juga untuk konstruk self efficacy memiliki arti bahwa setiap variasi perubahan konstruk self efficacy dapat dijelaskan sebesar $58,57 \%$ oleh variabel yang digunakan dalam penelitian ini yaitu self esteem.

Nilai-nilai signifikansi hubungan antar konstruk digunakan untuk menguji hipotesishipotesis yang telah dibangun berdasarkan teori yang dikembangkan dalam penelitian ini berdasarkan nilai t-statistic pada masingmasing jalur. Karena dalam hipotesis disebutkan hubungan masing-masing variabel adalah positif, maka penelitian ini menggunakan uji hipotesis satu arah (onetailed). Hasil perhitungan koefisien path dari bootstrapping menggunakan PLS 2.0 dapat dilihat pada Tabel 5 yang mana dari 3 hipotesis yang diusulkan dalam penelitian ini diperoleh 2 hipotesis terdukung secara positif signifikan. Hanya satu hipotesis yang tidak terdukung, yaitu hubungan antara self efficacy dengan prestasi akademik.

\section{Pembahasan}

Terdukungnya hipotesis 1 sesuai dengan hasil penelitian Schyns dan Collani (2002), Engko (2006) dan Indrawati (2014) yang menyatakan bahwa harga diri atau self esteem dapat meningkatkan keyakinan diri atau self efficacy seseorang dalam menyelesaikan tugas atau pekerjaannya. Hasil penelitian ini mengindikasikan bahwa self esteem yang semakin tinggi dapat meningkatkan kemampuan individu berupa pencapaian prestasi akademik yang baik melalui terbentuknya self efficacy yang tinggi. Dengan temuan ini, penulis beragumen bahwa semakin tinggi rasa percaya diri atau penghargaan terhadap diri sendiri yang semakin besar, dapat meningkatkan individu untuk semakin yakin akan kemampuan yang 
dimiliki dalam rangka menunjang prestasi pengauditan. akademik khususnya pada matakuliah

Tabel 5. Output Path Coefficients \& R-Square $\left(R^{2}\right)$

\begin{tabular}{clccccc}
\hline Hipotesisis & \multicolumn{1}{c}{ Path } & $\begin{array}{c}\text { Original } \\
\text { Sample }\end{array}$ & $\begin{array}{c}\text { T } \\
\text { Statistics }\end{array}$ & Alpha & \multicolumn{2}{c}{ Keterangan } \\
\hline H1 & $\begin{array}{l}\text { Self Esteem -> Self } \\
\text { Efficacy }\end{array}$ & 0,765354 & 20,187063 & 0,01 & Signifikan & Terdukung \\
\hline H2 & $\begin{array}{l}\text { Self Esteem -> Prestasi } \\
\text { Akademik }\end{array}$ & 0,202766 & 1,709987 & 0,05 & Signifikan & Terdukung \\
\hline H3 & $\begin{array}{l}\text { Self Efficacy -> Prestasi } \\
\text { Akademik }\end{array}$ & $-0,222944$ & 1,824557 & 0,05 & Signifikan & $\begin{array}{c}\text { Tidak } \\
\text { Terdukung }\end{array}$ \\
\hline
\end{tabular}

$R$-Square $\left(R^{2}\right)$ :

Prestasi Akademik 2,16\%

Self Efficacy $58,57 \%$

Sumber: Data primer diolah, 2018 (Output SmartPLS 2.0)

Hasil penelitian ini menunjukkan bahwa self esteem yang dimiliki oleh para responden adalah cenderung tinggi. Peneliti menduga bahwa para responden dalam mengerjakan tugas yang diberikan pada matakuliah pengauditan tersebut menunjukkan kepercayaan diri yang tinggi akan kemampuan yang dimilikinya. Sehingga mahasiswa memiliki keyakinan akan tugas-tugas yang dikerjakan tersebut akan berhasil untuk diselesaikan. Selain itu, terdukungnya hipotesis satu juga menunjukkan bahwa mahasiswa yang menjadi responden secara mayoritas merasa dirinya begitu berarti, berharga dan dapat diterima dalam lingkungan akademik dan dapat meningkatkan keyakinan terhadap kemampuan yang dimiliki dalam mengerjakan setiap tugas yang diberikan.

Temuan yang diperoleh dalam pengujian hipotesis dua ini sama dengan hasil penelitian yang dilakukan oleh Lockett dan Harrell (2003), Colquhoun dan Bourne (2012), Irawati dan Hajat (2012), dan Adhiputra (2015), yang menyatakan bahwa self esteem berkontribusi positif terhadap prestasi akademik mahasiswa. Hasil penelitian ini mengindikasikan bahwa mahasiswa yang memiliki self esteem tinggi akan membangkitkan rasa percaya diri, rasa berguna bagi orang lain dan rasa yakin akan kemampuan yang dimiliki secara positif maka cenderung akan memperoleh prestasi akademik yang baik. Pernyataaan tersebut sejalan dengan alasan yang dikemukan oleh Adhiputra (2015) bahwa mahasiswa yang memiliki kepercayaan diri tinggi dapat mencapai prestasi yang dia dan orang lain harapkan. Sehingga dengan self esteem yang tinggi, mahasiwa tersebut dapat memotivasi dirinya untuk bersungguh-sungguh mencapai apa yang dicita-citakan (Adhiputra, 2015) dan bersungguh-sungguh menumbuhkan keyakinan dan kemampuan dirinya untuk dapat mengatasi segala situasi dan kondisi dalam hidupnya dengan baik (Irawati dan Hajat, 2012).

Self efficacy dinyatakan dalam hipotesis 3 sebagai variabel yang diduga mempunyai hubugan positif kepada prestasi akademik. Walaupun nilai $t$-statistic lebih besar dari ttabel (lihat Tabel 5), akan tetapi koefisien yang diperoleh dalam pengujian ini mendapatkan hasil minus. Akibat dari hasil pengujian tersebut, maka hipotesis 3 tidak terdukung atau ditolak dan hasil tersebut berbeda dengan penelitian yang diperoleh Warsito (2009) dan Adhiputra (2015). Sehingga temuan dalam penelitian ini tidak sesuai dengan prediksi sebelumnya yaitu self efficacy 
dapat meningkatkan prestasi belajar mahasiswa.

Hasil yang diperoleh dalam pengujian hipotesis tiga tersebut menunjukkan bahwa prestasi akademik yang diperoleh dalam mata kuliah pengauditan tersebut tidak hanya dipengaruhi oleh self efficacy tetapi juga dipengaruhi faktor lain. Perlu diketahi bahwa self efficacy bersifat spesifik dalam tugas dan situasi yang dihadapi (Warsito, 2009). Seseorang dapat memiliki keyakinan yang tinggi pada suatu tugas dan situasi yang dihadapi, namun pada situasi dan tugas lain tidak memiliki keyakinan diri untuk menyelesaikan pekerjaan tersebut. Selain itu, tidak terdukungnya hipotesis tiga menunjukkan bahwa mahasiswa tidak memiliki keyakinan akan kemampuan dirinya dalam melakukan tugas atau tindakan yang diperlukan untuk menyelesaikan tugas-tugas dan ujian dalam matakuliah pengauditan. Jadi self efficacy yang dimiliki mahasiswa dalam melakukan tindakan menyelesaikan tugas, tidak dapat dimanfaatkan secara optimal dan mahasiswa tidak dapat melakukan sebuah tindakan dari kemampuan yang dimilikinya.

\section{PENUTUP}

Sebagai pengembangan dari model penelitian-penelitian sebelumnya, penelitian ini bertujuan untuk memberikan bukti empiris hubungan self esteem dan self efficacy terhadap prestasi akademik mahasiswa pada matakuliah pengauditan. Hasil yang didapat dalam penelitian ini memberikan dukungan yang cukup kuat terhadap tujuan tersebut. Hal ini ditunjukkan dengan terdukungnya 2 hipotesis dari 3 hipotesis yang dikembangkan. Dengan mayoritas hipotesis yang diajukan dalam penelitian ini terdukung secara positif signifikan, menunjukkan bahwa harga diri atau self esteem yang dimiliki mahasiswa dapat meningkatkan prestasi mahasiswa dan keyakinan diri atau self efficacy. Sedangkan hasil penelitian yang tidak sesuai dengan prediksi hipotesis adalah self efficacy yang tidak memiliki hubungan positif terhadap presatasi akademik. Tidak terdukungnya hipotesis tiga tersebut mengindikasikan bahwa mahasiswa belum memiliki keyakinan yang memadai terhadap kemampuan yang dimiliki. Selain itu, mahasiswa tidak dapat mengatasi suatu situasi yang dihadapi, tidak berusaha lebih keras lagi, dan mudah menyerah dengan permasalah atau rintangan yang dihadapi pada mata kuliah pengauditan.

Keterbatasan penelitian ini adalah sampel yang dipakai oleh penulis masih kurang representatif yang mana sampel diambil hanya pada mahasiswa yang mengikuti mata kuliah pengauditan 1 dan pengauditan 2. Sehingga diharapkan untuk penelitian berikutnya dapat menggunakan sampel yang lebih besar pada banyak kelas mata kuliah dan untuk variabel prestasi akademik dapat menggunakan ukuran yang lebih tepat, artinya tidak hanya pada nilai mata kuliah tersebut tetapi menggunakan IPK. Selain itu, penelitian selanjutnya diharapkan dapat menggunakan variabel personality lainnya atau faktor lingkungan dan perilaku yang sesuai dengan teori kognitif sosial sehingga dapat menunjukkan pengaruhnya terhadap prestasi akademik mahasiswa.

\section{REFERENSI}

Adhiputra, S. (2015). Keterkaitan Self Efficacy Dan Self EsteemTerhadap Prestasi Belajar Mahasiswa. Jurnal Fokus Konseling Volume 1 No. 2, Agustus, Hal. 151-161.

Afari, E., Ward, G., dan Lhine, M. S. (2012). Global self esteem and self efficacy correlates: Relation of academic achievement and self esteem among emirati students. International Education Studies, Vol. 5, No. 2.

Asmara, E. N., Supardi dan Ashari, S. (2016). Peran Organisasional Terhadap Pengembangan Bahan Ajar Pengauditan Berbasis ISA: Perspektif Dosen Pengauditan. Soedirman Accounting Review Vol. 1 No. 1, Hal. 1-12.

Bandura, A. (1977). Self-Efficacy: Toward a Unifying Theory of Behavioral Change. 
Psychological Review, Vol. 84, No. 2, hal. 191-215.

(1982). Self-efficacy mechanism in human agency. American Psychologist, 37, 122-147.

(1986). Social Foundations of Thought and Action: A Social Cognitive Theory. Englewood Cliffs, NJ: Prentice Hall.

(1989). Human Agency in Social Cognitive Theory. American Psychologist, 44, 1175-1184.

. (1997). Self-efficacy: The exercise of control. New York. W.H.Freeman.

Bandura, A dan Schunk, D.H. (1981). Cultivating competence, self-efficacy, and intrinsic interest through proximal selfmotivation. Journal of Personality and Social Psychology. No.69.

Baron, R. A. dan Byrne, B. (1994). Social Psychology. New York: John Willey \& Sons, Inc

Clemons, T.L. (2008). Underachieving gifted students: A social cognitive model. The National Research Centre on The Gifted and talented. Universutay of Virginia.

Collins, J. L. (1982). Self-efficacy and ability in achievement behavior. Paper presented at the meeting of the American Educational Research Association, New York.

Colquhoun, L. K., \& Bourne, P. A. (2012). Self esteem and academic performance of 4 th graders in two elementary schools in Kingston and St. Andrew, Jamaica. Asian Journal of Business Management, 4(1), 3657.

Cooper, Donald R., dan Schindler, Pamela S. (2006). Business Research Methods. McGraw-Hill.

Di Giunta, L., Alessandri, G., Gerbino, M., Kanacri, P. L., Zuffiano, A., \& Caprara, G. V. (2013). The determinants of scholastic achievement: The contribution of personality traits, self esteem, and academic self-efficacy. Learning and Individual Differences, 27, Hal. 102-108.

Engko, C. (2006). "Pengaruh Kepuasan Kerja Terhadap Kinerja Individual dengan Self efficacy dan Self Esteem Sebagai Variabel Intervening". Simposium Nasional Akuntansi 9 Universitas Andalas. Padang, Hal 125.

Fajarwati, S. (2015). Hubungan Antara Self Control Dan Self Efficacy Dengan Prokrastinasi Akademik Pada Mahasiswa BK UNY Yang Sedang Menyusun Skripsi. Jurnal Bimbingan dan Konseling Vol. 8, No. 4, Hal. 1-11.

Fasikhah, S.S. dan Fatimah, S. (2013). Self Regulated Learning (SRL) Dalam Meningkatkan Prestasi Akademik Pada Mahasiswa. Jurnal Ilmiah Psikologi Terapan, Vol. 1, No. 1, Januari, Hal. 145155.

Haripoernomo,T. (2003). Hubungan prestasi akademik, kematangan siswa dan kinerja siswa dalam praktek industri dengan kesiapan terhadap dunia kerja pada SMK kota Malang. Thesis, tidak diterbitkan. Program Pascasarjana IKIP Malang.

Hartono, Jogiyanto M. (2008). Sistem Informasi Keperilakuan. Edisi Revisi, Andi, Yogyakarta.

Hartono, Jogiyanto M. dan Abdillah, Willy. (2009). Konsep Aplikasi PLS Untuk Penelitian Empiris. BP Fakultas Ekonomika dan Bisnis UGM-Yogyakarta.

Indrawati. (2014). Pengaruh Self Esteem, Self Efficacy Dan Kepuasan Kerja Terhadap Kinerja Karyawan (Studi Kasus Perawat RS Siloam Manado). Jurnal Riset Bisnis dan Manajemen Vol. 2, No. 4, Hal. 12-24.

Irawati, N dan Hajat, N. (2012). Hubungan Antara Harga Diri (Self Esteem) Dengan Prestasi Belajar Pada Siswa SMKN 48 Di Jakarta Timur. Econosains Vol. X, No. 2, Agustus, Hal. 193-210.

Kilapong, S. N. (2013). Kepemimpinan Transformasional, Self Efficacy, Self Esteem Pengaruhnya terhadap Kepuasan Kerja Karyawan PT. Tropica Cocoprima Manado. Jurnal Riset Ekonomi, Manajemen, Bisnis dan Akuntansi, I (4), 141-150. 
Latifah, M, Hernawati, N dan Nurhayati, S. (2011). Kecerdasan Emosional, Kematangan Sosial, Self Esteem Dan Prestasi Akademik Mahasiswa Lulusan Pesantren. Jurnal Ilmiah Kel dan Kons, Vol. 4, No. 1, Januari, Hal. 66-73.

Lockett, C. T., \& Harrell, J. P. (2003). Racial identity, self esteem, and academic achievement: Too much interpretation, to little supporting data. Journal of Black Psychology, 29 (3), Hal. 325-336.

Mukhid, A. (2009). SELF-EFFICACY (Perspektif Teori Kognitif Sosial dan Implikasinya terhadap Pendidikan). Jurnal Tadrîs, Vol 4, No 1, Hal. 106-122.

Rosenberg, M. (1980). Conceiving the self. New York: Basic Books.

Sapariyah, A, R. (2008). "Pengaruh Self Esteem, Self Efficacy and Locus Of Control Terhadap Kinerja Karyawan Dalam Perfektif Balance Scorecard Pada Perum Pegadaian Boyolali". Sekolah Tinggi IImu Ekonomi AUB. Solo, Hal 178.

Schunk, D. H. (1981). Modeling and Attributional Effects on Children's Achievement: A Self-efficacy Analysis. Journal of Educational Psychology. No.73.
Schyns, B. dan G. V. Collani. (2002). A New Occupational Self Efficacy Scale and its Relation to persona lity constructs and organizational variable. European jurnal of work and organizational psychology 11 (2), 219-241

Tuanakotta, Theodorus M. (2013). Audit Berbasis ISA (International Standards on Auditing). Salemba Empat.

Warsito, H. 2009. Hubungan Antara SelfEfficacy Dengan Penyesuaian Akademik Dan Prestasi Akademik (Studi Pada Mahasiswa FIP Universitas Negeri Surabaya). Pedagogi Jurnal Ilmiah Ilmu Pendidikan, Vol. IX, No. 1, Hal. 29-47.

Wibowo, Satrio B. (2016). Benarkah Self Esteem Mempengaruhi Prestasi Akademik? Jurnal Humanitas, Vol. 13, No. 1, Februari, Hal. 72-83.

Zheng, C., Erickson, A. G., Kingston, N. M., dan. Noonan, P. M. (2014). The relationship among self-determination, self-concept, and academic achievement for students with learning disabilities. Journal of Learning Disabilities, 47 (5). Hal. 462-474. 
